\title{
Penerapan Metode Tutor Sebaya Dalam Meningkatkan Hasil Belajar Passing Atas Pada Permainan Bola Voli Mini
}

\author{
Helmi Patamani \\ Guru SDN 07 Kabupaten Pohuwato \\ helmi@gmail.com
}

\begin{abstract}
Abstrak
Tujuan penelitian ini adalah untuk meningkatkan hasil belajar passing atas bola voli mini melalui tutor sebaya siswa kelas V SDN 07 Marisa Kabupaten Pohuwato.Penelitian ini adalah Penelitian Tindakan Kelas (PTK) yang dilakukan dalam dua siklus. Subyek penelitian adalah siswa kelas V SDN 07 Marisa tahun Pelajaran 2015/2016 yang berjumlah 30 siswa. Data penelitian ini adalah data primer meliputi data hasil belajar siswa, keaktifan siswa dan guru selama pembelajaran, dan data penggunaan bantuan tutor sebaya selama pembelajaran. Data sekunder meliputi data hasil belajar passing atas siswa, pratindakan, rencana pelaksanaan pembelajaran, silabus, dan kurikulum yang diperoleh dari dokumen yang dimiliki guru dan sekolah. Data dikumpulkan melalui tes praktik, dan pengamatan. Dari hasil analisa data diketahui bahwa, hasil belajar siswa sebelum diadakan tindakan adalah 12 siswa (40\%) tuntas belajar dan 18 siswa (60\%) belum tuntas belajar. Pada siklus I ketuntasan belajar mencapai $72,22 \%$ yaitu 22 siswa telah tuntas belajar dan 8 siswa $(27,78 \%)$ belum tuntas belajar. Pada siklus II ketuntasan belajar mencapai $90 \%$ yaitu 27 siswa telah tuntas belajar dan 3 siswa (10\%) belum tuntas belajar. Hal ini berarti hasil belajar siswa kelas V SDN 07 Marisa pada pembelajaran passing atas dapat meningkat melalui metode tutor sebaya.
\end{abstract}

Kata kunci:

Hasil Belajar, Bola Voli Mini, Passing Atas, Model Tutor Sebaya

\section{PENDAHULUAN}

Permainan dan olahraga meliputi olahraga tradisional, permainan. eksplorasi gerak, keterampilan lokomotor non-lokomotor, dan manipulatif, atletik, kasti, rounders, kippers, sepak bola, bola basket, bola voli, tenis meja, tenis lapangan, bulu tangkis, dan beladiri, serta aktivitas lainnya, olahraga tradisionaldan aktivitas luar kelas. Dalam pendidikan jasmani permainan merupakan olahraga yang paling digemari siswa, salah satu di antaranya adalah permainan bola voli mini.

Bola voli merupakan salah satu cabang olahraga permainan yang termasuk dalam materi pokok pendidikan jasmani. Banyak manfaat yang diperoleh dengan bermain bola voli yang diantaranya adalah dapat membentuk sikap tubuh yang baik meliputi anatomis, fisiologis, kesehatan dan kemampun jasmani. Manfaatnya bagi rohani yaitu kejiwaan, kepribadian dan karakter akan tumbuh ke arah yang sesuai dengan tuntutan masyarakat

Penggunaan metode pembelajaran yang kurang menyenangkan menyebabkan siswa kurang termotivasi untuk belajar teknik passing atas bola voli. Selama ini teknik yang diberikan guru pendidikan jasmani dalam mengajar passing atas masih sulit dipelajari oleh siswa, akibatnya siswa kurang terampil dalam melakukan passing atas bola voli. Terbukti dari hasil evaluasi, baru $40 \%$ siswa yang telah dapat melakukan teknik passing atas dengan baik dan benar dan sisanya $60 \%$ siswa masih belum menguasai teknik passing atas dengan baik dan benar. Kondisi demikian apabila dibiarkan akan mempengaruhi pencapaian prestasi belajar siswa. Hal tersebut menunjukkan adanya suatu permasalahan yang harus dicari jalan keluarnya. 
Berdasarkan permasalahan tersebut, maka peneliti menggunakan metode pembelajaran yang dapat membantu siswa kelas V SDN 07 Marisa untuk dapat melakukan passing atas dengan baik dan benar, yaitu metode tutor sebaya. Penggunaan metode tutor sebaya diharapkan dapat meningkatkan penguasaan siswa terhadap teknik passing atas, seperti yang disampaikan oleh Abu Ahmadi dan Widodo Supriyono, bahwa tutor sebaya adalah siswa yang ditunjuk atau ditugaskan membantu temannya yang mengalami kesulitan belajar, karena hubungan teman umumnya lebih dekat dibandingkan hubungan guru dengan siswa.

\section{KAJIAN TEORI \\ Hasil Belajar}

Menurut Mulyono Abdurrahman (2003:37) "Hasil belajar adalah kemampuan yang diperoleh anak setelah melalui kegiatan belajar". Dalam kegiatan pembelajaran tujuan yang ingin dicapai ditentukan sebelumnya. Anak yang dikatakan berhasil adalah mereka yang dapat mencapai tujuan-tujuan pelajaran yang telah ditentukan sebelumnya.

Dimyati dan Mujiono (2006:3) memaparkan bahwa "Hasil belajar merupakan hasil dari suatu interaksi tindak belajar dan tindak mengajar". Hasil belajar merupakan pencapaian tujuan pengajaran dan kemampuan mental siswa. Setelah selesai mempelajari materi, diadakan evaluasi hasil belajar untuk mengetahui tingkat pencapaian tujuan pembelajaran yang telah ditentukan sebelumnya, sebelum dilanjutkan pada jenjang yang lebih tinggi. Sedangkan menurut Sudjana (Padmono, 2002:37) menyatakan bahwa hasil belajar adalah kemampuankemampuan yang dimiliki siswa atau mahasiswa setelah ia menerima pengalaman belajarnya. Berdasarkan teori di atas dapat disimpulkan bahwa hasil belajar adalah kemampuan yang diperoleh anak setelah melalui kegiatan belajar. Hasil belajar merupakan penguasaan berbagai macam keterampilan, pengetahuan setelah siswa memperoleh pengalaman belajar. Dalam kegiatan pembelajaran tujuan yang ingin dicapai ditentukan sebelumnya. Anak yang dikatakan berhasil adalah mereka yang dapat mencapai tujuan-tujuan pembelajaran yang telah ditentukan sebelumnya.

\section{Bola Voli Mini}

Permainan bola voli mini merupakan pembelajaran pendidikan jasmani yang diterapkan di sekolah dasar. Jumlah pemain yang dibutuhkan dalam satu regu 4 orang pemain dengan 2 orang cadangan dan pertandingan 2 set kemenangan (PP.PBVSI, 1995: 73). Lapangan Bola voli mini berukuran panjang 12 meter, lebar 6 meter, tinggi net putra 2,10 meter, putri 2 meter, dan bola yang digunakan nomor 4 dengan berat 230-250 gram (Tim Bina Karya Guru, 2004: 18).

Menurut Rukmana (1990: 24) salah satu cara melatih bola voli mini bagi anak usia 9-13 tahun adalah sebagai berikut:

1) Latihan Pengenalan Bola

Latihan pengenalan sangat penting dilakukan agar siswa terlebih dahulu mengenal bola voli. Untuk menanamkan rasa cinta terhadap permainan bola voli mini terlebih dahulu diperkenalkan bermacam-macam latihan yang menyenangkan, sehingga anak-anak merasa senang dan menyukai, akhirnya mencintai bola voli mini. Misalnya, lempar tangkap bola dengan menggunakan bola plastik).

2) Latihan Menuju Pembentukan Fisik Bola voli

Dalam permainan Bola voli mini kesiapan fisik yang prima sangat menunjang tercapainya prestasi yang optimal, tentu saja disesuaikan dengan usia serta perkembangan jiwa. Misalnya, siswa dilatih lompat zig-zag sambil melewati bola.

3) Latihan Teknik Dasar Bola voli 
Setelah siswa siap secara fisik dan mental, selanjutnya dilakukan latihan teknik dasar permainan bola voli. Penerapan latihan teknik-teknik dasar bola voli mini dilakukan secara bertahap. Teknik-teknik dasar bola voli mini meliputi: servis, passing, receive, spike, dan block Metode Tutor Sebaya

Tutor sebaya adalah siswa yang ditunjuk atau ditugaskan membantu temannya yang mengalami kesulitan belajar, karena hubungan teman umumnya lebih dekat dibandingkan hubungan guru dengan siswa (Abu Ahmadi dan Widodo Supriyono, 2004). Dedi Supriyadi mengemukakan, bahwa tutor sebaya adalah seorang atau beberapa orang siswa yang ditunjuk dan ditugaskan untuk membantu siswa yang mengalami kesulitan belajar.

Nasution (1992) berpendapat bahwa tutor, adalah orang yang dapat membantu murid secara individual. Menurut Ischak dan Warji (1987) tutor sebaya artinya siswa yang mengalami kesulitan belajar diberi bantuan oleh teman-teman mereka sekelas yang punya umur sebaya dengan dia.

Berdasarkan teori-teori di atas, maka dapat disimpulkan bahwa tutor sebaya adalah bagaimana mengoptimalkan kemampuan siswa yang berprestasi dalam satu kelas untuk mengajarkan atau menularkan kepada teman sebaya mereka yang kurang berprestasi. Sehingga siswa yang kurang berprestasi bisa mengatasi ketertinggalan. Pembimbingan dalam pelajaran yang diberikan oleh seorang siswa kepada siswa lain, sedangkan mereka (antara pembimbing dan yang dibimbing) adalah teman sekelas atau teman sebangku yang usianya relatif sama, dan siswa yang kurang paham bisa bertanya langsung kepada teman sebangkunya (tutor yang di tunjuk) sehingga kondisi kelas pun bisa hidup karena siswa tidak malu bertanya ketika mereka tidak paham

\section{METODE PENELITIAN}

Penelitian ini dilaksanakan di SDN 07 Marisa pada Tahun Pelajaran 2015/2016, yaitu dari bulan April 2016 sampai dengan bulan Juni 2016. dengan subyek penelitian ini adalah siswa kelas V SDN 07 Marisa berjumlah 30 orang yang atas: 15 orang berjenis laki-laki dan 15 orang berjenis kelamin perempuan.

Penelitian ini menggunakan metode Penelitian Tindakan Kelas yang terdiri dari 2 siklus, langkah-langkah dalam siklus penelitian tindakan kelas ini terdiri dari atas empat komponen, yaitu: 1) rencana, 2) tindakan, 3) observasi, 4) refleksi.

Data yang diperlukan dalam penelitian tindakan kelas ini berupa catatan hasil pengamatan. Hasil pengamatan tersebut dikumpulkan melalui pengamatan hasil observasi dan hasil tes siswa Indikator keberhasilan tindakan dalam penelitian ini adalah meningkatnya hasil pembelajaran passing atas melalui metode tutor sebaya yang dapat dilihat pada perolehan nilai siswa kelas $\mathrm{V}$ secara individual yang didasarkan pada Kriteria Ketuntasan Minimum (KKM) yaitu 75 dan didukung dengan perolehan nilai ketuntasan secara klasikal yaitu $75 \%$ 


\section{HASIL PENELITIAN}

\section{Hasil Penelitian Siklus I}

Deskripsi data yang diambil setelah tindakan siklus I disajikan dalam bentuk tabel sebagai berikut:

Tabel 1

Deskripsi Data Hasil Belajar Siklus I

\begin{tabular}{|c|c|c|c|}
\hline No & Kriteria & Jumlah Anak & Prosentase \\
\hline 1. & Tuntas & 22 & $72,22 \%$ \\
\hline 2. & Belum tuntas & 8 & $27,28 \%$ \\
\hline \multicolumn{2}{|r|}{ JUMLAH } & 30 & $100 \%$ \\
\hline
\end{tabular}

Berdasarkan hasil tersebut disimpulkan bahwa hasil belajar passing atas bola voli mini siswa baru mencapai Kategori cukup. Dan untuk memperbaiki kelemahan dan kekurangan tindakan siklus I, langkah-langkah antisipasinya adalah sebagai berikut:

$\checkmark$ Agar teknik passing atas siswa semakin sempurna, maka perlu latihan yang berulang-ulang

$\checkmark$ Peneliti memberikan penghargaan/penguatan kepada siswa yang telah melakukan passing atas dengan benar

Untuk mengatasi siswa yang bercanda dengan tutor sebaya, maka peneliti akan lebih perhatian dan mengkondisikan jalannya pembelajaran.

\section{Hasil Penelitian Siklus II}

Pelaksanaan tindakan siklus II merupakan tindak lanjut dari hasil analisis dan refleksi yang dilakukan pada siklus I. hasil belajar siswa pada siklus I menunjukkan peningkatan, akan tetapi belum memenuhi target pencapaian, sehingga dilakukan tindakan siklus II dengan mengacu pada tindakan siklus I. Deskripsi data yang diambil setelah tindakan siklus II disajikan dalam bentuk tabel sebagai berikut:

Tabel 2

Deskripsi Data Hasil Belajar Siklus II

\begin{tabular}{|c|c|c|c|}
\hline No & Kriteria & $\begin{array}{c}\text { Jumlah } \\
\text { Anak }\end{array}$ & Prosentase \\
\hline 1. & Tuntas & 27 & $90 \%$ \\
\hline 2. & Belum tuntas & 3 & $10 \%$ \\
\hline \multicolumn{2}{|c|}{ JUMLAH } & 30 & $100 \%$ \\
\hline
\end{tabular}

Berdasarkan hasil deskripsi data siklus II, hal ini berarti indikator keberhasilan tindakan telah tercapai. Sehingga penelitian tidak perlu dilanjutkan untuk siklus berikutnya lagi

\section{PEMBAHASAN}

Perbaikan pembelajaran melalui penelitian tindakan kelas tentang passing atas bola voli mini melalui metode bantuan tutor sebaya telah dapat meningkatkan keaktifan dan semangat belajar siswa sehingga tujuan perbaikan tercapai dengan optimal.

Penggunaan metode bantuan tutor sebaya terbukti sangat membantu peningkatan hasil belajar siswa hal ini dikarenakan kelebihan penggunaan metode tutor sebaya banyak memberikan keuntungan di antaranya siswa yang takut atau segan dengan guru menjadi tidak takut karena belajar dengan teman sebaya. Meskipun siswa belajar dengan teman, akan tetapi tidak 
mengurangi pencapaian nilai afektif, siswa tetap belajar dengan penuh percaya diri, semangat, disiplin, jujur, dan penuh tanggung jawab.

Peningkatan hasil belajar siswa dapat dilihat dari tabel-tabel yang disajikan sebagi berikut:

Tabel 3

Perbandingan Hasil Belajar Pratindakan, Siklus I, dan Siklus II

\begin{tabular}{|l|l|c|c|c|}
\hline No & Kriteria & Pratindakan & Siklus I & Siklus II \\
\hline 1. & Tuntas & $44 \%$ & $72 \%$ & $90 \%$ \\
\hline 2. & Belum tuntas & $66 \%$ & $28 \%$ & $10 \%$ \\
\hline \multicolumn{2}{|c|}{ JUMLAH } & $100 \%$ & $100 \%$ & $100 \%$ \\
\hline
\end{tabular}

Perbandingan hasil belajar passing atas bola voli mini siswa antar siklus yaitu dari pratindakan diperoleh 12 siswa (40\%) telah tuntas dan 18 siswa (60\%) belum mencapai ketuntasan. Setelah dilakukan tindakan siklus I, 13 siswa (72\%) telah mencapai ketuntasan belajar dan 5 siswa (28\%) belum tuntas belajar. Pada siklus II, 16 siswa (89\%) telah mencapai ketuntasan belajar dan 2 siswa (11\%) belum mencapai ketuntasan belajar.

Peningkatan jumlah ketuntasan hasil belajar dari pratindakan sampai siklus II dapat dilihat pada tabel berikut ini:

Tabel 4

\begin{tabular}{|l|l|c|c|c|}
\hline No & Kriteria & Pratindakan & Siklus I & Siklus II \\
\hline 1. & Tuntas & $40 \%$ & $72,22 \%$ & $89 \%$ \\
\hline 2. & Belum tuntas & $60 \%$ & $27,28 \%$ & $11 \%$ \\
\hline \multicolumn{2}{|c|}{ JUMLAH } & $100 \%$ & $100 \%$ & $100 \%$ \\
\hline
\end{tabular}

Pada pratindakan siswa yang telah mencapai nilai KKM 12 anak (40\%) dan sisanya 18 anak $(60 \%)$ belum mencapai nilai KKM. Pada siklus I siswa yang telah mencapai nilai KKM 22 anak $(72,22 \%)$ dan sisanya 8 anak $(27,28 \%)$ belum mencapai nilai KKM. Pada siklus II siswa yang telah mencapai nilai KKM 27 anak (90\%) dan sisanya 3 anak (10\%) belum mencapai nilai KKM. Dari pratindakan ke siklus I jika dibandingkan terlihat kenaikan hasil belajar siswa mengalami kenaikan 10 anak $(32,22 \%)$ dan dari siklus I ke siklus II mengalami kenaikan 5 anak $(17,78 \%)$. 


\section{KESIMPULAN}

Berdasarkan analisis data hasil belajar passing atas bola voli mini siswa kelas V SDN 07 Marisa Tahun Pelajaran 2015/2016 dapat diperoleh hasil sebagai berikut:

1. Pada pratindakan dari 30 siswa, terdapat 12 siswa (40\%) yang tuntas belajar.

2. Pada akhir siklus I dari 30 siswa, terdapat 22 siswa $(72,22 \%)$ yang tuntas belajar.

3. Pada akhir siklus II dari 30 siswa, 27 siswa (90\%) telah tuntas belajar.

Dengan demikian dapat ditarik kesimpulan bahwa penerapan metode bantuan tutor sebaya dapat meningkatkan hasil belajar passing atas bola voli mini siswa kelas V SDN 07 Marisa Kecamatan Marisa Kabupaten Pohuwato Tahun Pelajaran 2015/2016

\section{DAFTAR PUSTAKA}

Abu Ahmadi, Widodo Supriyono. 2004. Psikologi Belajar. Jakarta: Rineka Cipta.

Agus KristiRinoto.2010. Penelitian Tindakan Kelas (PTK) Dalam Pendidikan Jasmani \& Kepelatihan Olahraga. Surakarta: UNS Press.

.Arma Abdoellah. 1981. Olahraga Untuk Perguruan Tinggi. Yogyakarta : Sastra Hudaya.

Badudu Zain. 1992. Kamus Umum Bahasa Indonesia. Jakarta: Balai Pustaka.

Beutelstahl, Dieter. 2007. Belajar Bermain Bola Volley. Bandung: Piopir Jaya.

Dadang Heryana, Giri Verianti. 2010. Pendidikan Jasmani Olahraga dan Kesehatan untuk Siswa SD-MI Kelas V. Jakarta: Aneka Ilmu.

Depdiknas. 2003. Kurikulum 2004 Standar Kompetensi (Mata Pelajaran Pendidikan Jasmani Tingkat SD/MI. Jakarta: Depdiknas

Hamalik, Oemar. 2004. Media Pendidikan. Bandung: PT Aditya Bakti

PP.PBVSI. 1995. Jenis-jenis Permainan Bola voli. Jakarta: PBVSI.

Purwanto, M. Ngalim, MP. 1997. Psikologis Pendidikan. Bandung: PT Rosda Karya.

Slameto. 1993. Belajar dan Faktor-Faktor yang Mempengaruhinya. Jakarta : Rineka Cipta.

Sudiarto. 1990. Strategi Pembelajaran. Jakarta: Dirjend Dikti.

Suharsimi Arikunto. 1993. Penelitian Tindakan Kelas (PTK). Jakarta: Departemen Pendidikan dan Kebudayaan.

Syarifuddin Aip. 1991. Pengetahuan Olahraga. Jakarta: CV Baru

Viera, Barbara L. 2000. Bolavoli. (Tingkat Pemula) diterjemahkan oleh Monti. Jakarta: Raja Grafindo Persada. 